\title{
S111041
}

\section{火山灰を用いた歯面仕上げ法の開発に関する基礎研究* （浸炭焼入れ歯車の歯面性状に及ぼす加工条件の影響）}

\author{
中西 勉 ${ }^{* 1}$, 山本玩也 ${ }^{* 2}$, 福間絵理香 ${ }^{* 2}$, 鄧 鋼 $^{* 1}$

\section{Development of Tooth Surface-Finishing Method by Using Volcanic-Ashes (Influence of Machining Condition on Tooth Surface Texture of Case-Carburized Gears)}

\author{
Tsutomu NAKANISHI ${ }^{* 1}$, Takuya YAMAMOTO, Erika FUKUMA and Gang DENG \\ ${ }^{* 1}$ University of Miyazaki, Faculty of Engineering \\ Gakuen Kibanadai-nishi 1-1, Miyazaki-shi, Miyazaki 889-2192 Japan
}

In order to obtain the high surface durability of power transmission gears and to promote environmental protection, the tooth surface-finishing method using a plastic material was developed. In this paper, the influence of machining condition on tooth surface texture of case-carburized gears was studied. First, the various plastic materials could be obtained by mixing the white petrolatum with the volcanic-ashes in different particle sizes. Secondly, the tooth surface of case-carburized gear was finished by use of a plastic material. Thirdly, the tooth surface was investigated by using a scanning electron microscopy and a surface texture measuring instrument. From these experiments, the following results are obtained: By applying the designed tooth surface-finishing method in the case-carburized gear tooth, the randomly-rough surface after heat treatment process almost become smooth. In the case of finished tooth surface, it is found that the values of three dimensional roughness parameters decrease with the increase of finishing distance and particle size of the volcanic-ashes.

Key Words : Gear, Surface-Finishing Method, Volcanic-Ashes, SEM Micrograph, Surface Texture, Surface Roughness

\section{1. 粕 言}

動力伝達用の浸炭焼入れ歯車の加工に対しては，歯切り加工後浸炭焼入れ焼戻しの熱処理が施され，高精度化 並びに高強度化のために歯面研削やギヤホーニングなどの歯面仕上げが必要とされている ${ }^{(1)}{ }^{(2)}$. また, 小型の浸 炭焼入れ歯車の強度に対しては, 最近の技術で歯の曲げ強さが向上し, 歯面強さの向上が必要とされている ${ }^{(3)}$ (4). そこで, 本研究では, 資源有効利用の観点と浸炭焼入れ歯車の生産性向上並びに歯面強さ向上の観点から, 南九 州に多く存在する天然資源の火山灰を用いて歯面を簡便に滑らかにする歯面仕上げ法 ${ }^{(5)}$ を適用し, 歯面性状に及 ぼす加工条件の影響を調べた，具体的には，まず，歯面を滑らかにする可塑性材料として，火山灰に白色ワセリ ンを混合した流動性火山灰を種々生成した．次に，歯面仕上げ用基礎実験装置を用いてシェービング浸炭焼入れ 歯面を種々の流動性火山灰で仕上げ，仕上げ前後の歯面状況と歯面形状並びに歯面粗さを走查型電子顕微鏡

(Scanning Electron Microscope 以後 SEM と記す) とデジタル表面形状粗さ測定機を用いて観察・測定し，それぞ れを比較検討した.

\section{2. 流動性火山灰の生成}

\section{$2 \cdot 1$ 火山灰の粒徍および成分}

図 1 に, 用いた 3 種類の火山灰の二次電子像を示す. なお, 図 1 において, 火山灰 VA150・VB250・VC590 は, ふるい網の目開き ${ }^{(6)}$ がそれぞれ $150 \mu \mathrm{m} \cdot 250 \mu \mathrm{m} \cdot 590 \mu \mathrm{m}$ で精製された九州産である. 図 1 などから，用いた 3

\footnotetext{
${ }^{* 1}$ 正員, 宮崎大学 工学部（广889-2192 宮崎市学園木花台西 1-1）

"2 宮崎大学 大学院 工学研究科

E-mail: t0d115u@cc.miyazaki-u.ac.jp
} 
種類の火山灰の粒子の形状並びに大きさは，いずれも極めてランダムなこと，明らかに火山灰 VA 150 ・VB 250 ・ VC590 の順に粒径が大きくなることがわかった.

な押，火山灰の主成分は， $\mathrm{SiO}_{2}$ (約 $80 \mathrm{wt} \%$ ） と $\mathrm{Al}_{2} \mathrm{O}_{3}$ (約 $10 \mathrm{wt} \%$ ） であり，二酸化ケイ素（シリカ）と酸化 アルミニウム (アルミナ) は，それぞれ遊離砥粒加工 (7)で利用されている.

\section{$2 \cdot 2$ 流動性火山灰の生成}

本実験で適用した歯面仕上げ法は，流動性火山灰を歯車の歯面上に流動させ，歯面を滑らかにする加工法 ${ }^{(5)}$ である. したがって，火山灰に適当な可塑性を与えるために，軟膏としても用いられる石油から得た炭化水素類 の混合物を脱色して精製した白色ワセリン ${ }^{(8)}$ を混練（火山灰と白色ワセリンの重量比を 9:1） し，可塑性材料 の流動性火山灰を生成した，なお，生成した 3 種類の流動性火山灰は，それぞれ含まれる火山灰で分類して，以 下 MVA150, MVB250, MVC590 と標記した。

\section{3. 試験歯車の諸元および歯面仕上げ法}

\section{$3 \cdot 1$ 試検歯車の諸元および製作工程}

試験歯車は, 二輪自動車用駆動系歯車として用いられている小型の平歯車で, モジュール: 2.5 , 圧力角 : $20^{\circ}$, 歯数 : 32 枚, 歯幅: $14.2 \mathrm{~mm}$, 外径 : $87 \mathrm{~mm}^{(5)}$ である.

試験歯車の加工工程は，鍛造材（材種 JIS SCM420 相当品）のギヤブランクを機械加工し，ホブ切り後シェー ビングを実施し, 浸炭焼入れ焼戻しの熱処理（歯面硬さ $550 \mathrm{HV}$ ・歯面付近最大硬さ $750 \mathrm{HV}$ ・歯面浸炭深さ $550 \mathrm{HV}$ の表面からの深さ位置 $0.5 \mathrm{~mm}$ 程度）と歯車内径等の仕上げ機械加工 ${ }^{(5)}$ とした.

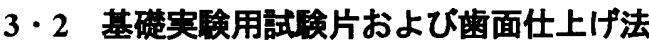

基礎実験用試験片は，試験歯車から一歯の歯部のみをワイヤーカット放電加工機を用いて，切出し製作した. なお，歯面仕上げ実験には，筆者らが設計・製作した単純な構造（フレーム・押し棒駆動装置・シリンダー・試 験片押し棒・負荷測定用ロードセル・移動距離測定用変位変換機など）の歯面仕上げ用基礎実験装置(5)を用いた.

歯面仕上げ法は，流動性火山灰中を基礎実験用試験片が移動する方法，すなわち，歯面上を流動性火山灰が移 動する方法(5)とした。

\section{$3 \cdot 3$ 歯面仕上げの実験条件および歯面状況の镥察法}

表 1 に, 菌面仕上げの実験条件を示寸. 表 1 において, 実験条件は, 3 種類の流動性火山灰を用いて, [FT-1] が MVA150，[FT-2]・ [FT-3]・[FT-4] が MVB250，[FT-5] が MVC590 で，それぞれ，流動性火山灰中の試験片（歯 面）の移動距離 $L$ が $420 \mathrm{~mm}, 140 \cdot 280 \cdot 420 \mathrm{~mm}, 420 \mathrm{~mm}$ とした.

次に，歯面仕上げ前後の歯面状態の変化については，走查型電子顕微鏡を用いて二次電子像を観察するととも に表面形状粗さ測定機を用いて三次元歯面形状を測定した.

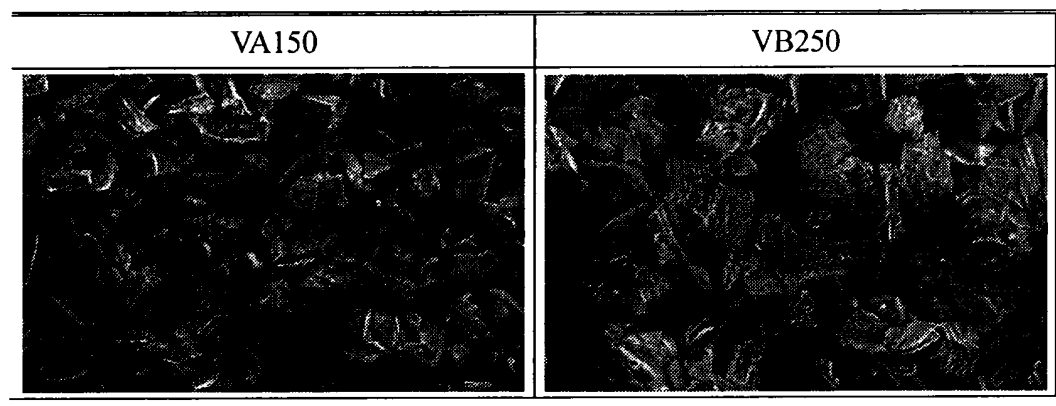

Fig. 1 SEM micrographs of volcanic-ashes

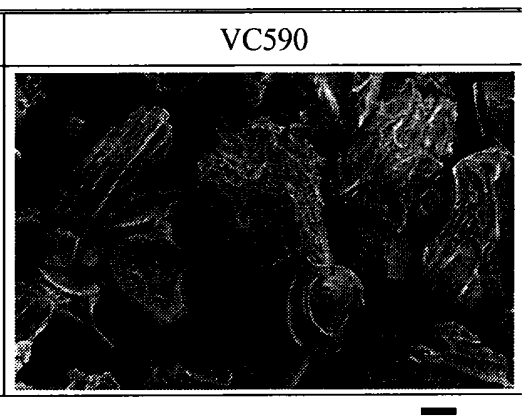

$1 \overline{00 \mu \mathrm{m}}$

Table 1 Experimental conditions of surface-finishing tests

\begin{tabular}{ll|c|c|c|c|c}
\hline Test No. & & FT-1 & FT-2 & FT-3 & FT-4 & FT-5 \\
\hline Volcanic-ashes & & VA150 & \multicolumn{3}{|c|}{ VB250 } & VC590 \\
\hline Plastic material* & & MVA150 & \multicolumn{3}{|c|}{ MVB250 } & MVC590 \\
\hline Length of movement & $L \mathrm{~mm}$ & 420 & 140 & 280 & 420 & 420 \\
\hline
\end{tabular}




\section{4. 実験結果および考察}

\section{4・1 走査型電子顕微鏡による歯面詳細钼察結果}

図 2 に, 歯面仕上げ前後の歯面における詳細観察結果を示寸。ここで, 図 2 において, 観察結果の代表例は, いずれもシェービング浸炭焼入れ蒌面と仕上げ蒾面（実験番号[FT-1] MVA150，[FT-4] MVB250，[FT-5]MVC590） で，歯面のピッチ線付近で歯形方向約 $200 \mu \mathrm{m}$ と歯すじ方向約 $350 \mu \mathrm{m}$ の長方形領域である.

図 2 などから，本実験条件において，シェービング浸炭焼入れ歯面では，浸炭焼入れ焼戻しの熱処理により歯 面に不規則な表面あれが存在し, シェービング加工の痕跡がわずかに確認できること, 次に, MVA150, MVB250, MVC590の流動性火山灰を用いた仕上げ歯面では，いずれも，熱処理工程後の不規則な表面あれが消失し，シェ ービング加工の痕跡が明確に確認できる場合と消失している場合のあることがわかった．

\section{$4 \cdot 2$ 表面形状粗さ測定機による歯面形状測定結果}

図 3 と図 4 に，歯面仕上げ前後の歯面における三次元歯面形状測定結果を示寸。ここで，図 3 と図 4 は，測定 歯面の鳥瞰図（歯形方向スキャン表示）と平面図（等高線表示）で, 歯車対の歯面接触における弾性変形を考慮

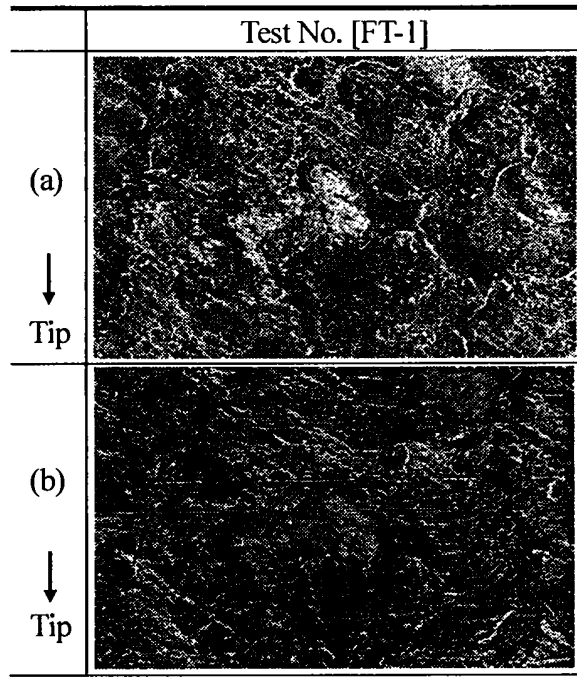

(a) : Before finishing (shaved tooth surface)
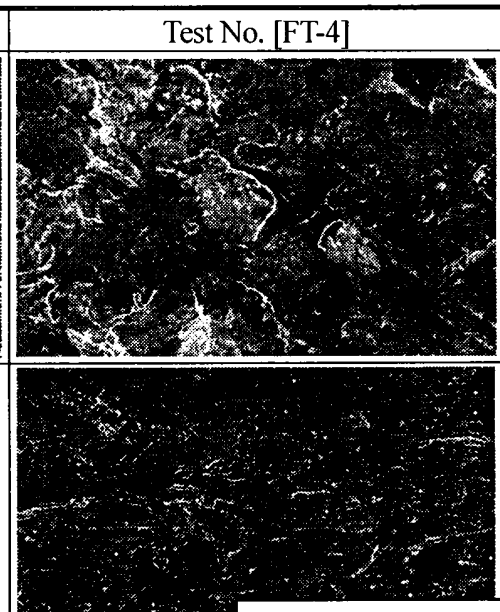

$\longleftarrow$ Direction of movement (for gear)

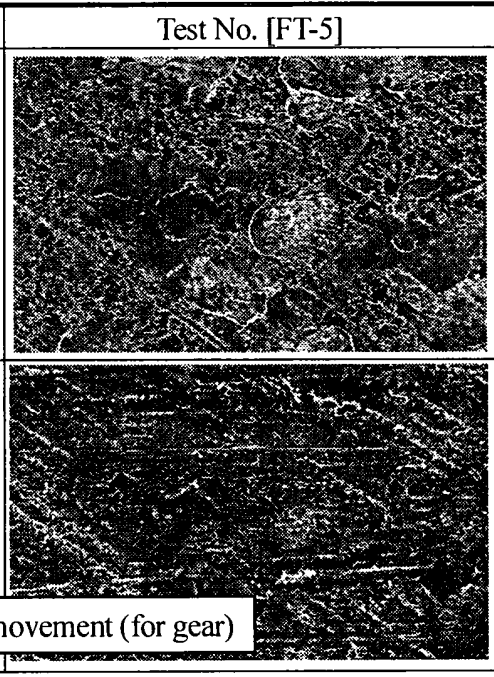

(b) : After finishing (surface-finished tooth surface)

Fig. 2 SEM micrographs of tooth surface before and after finishing (near the pitch line)

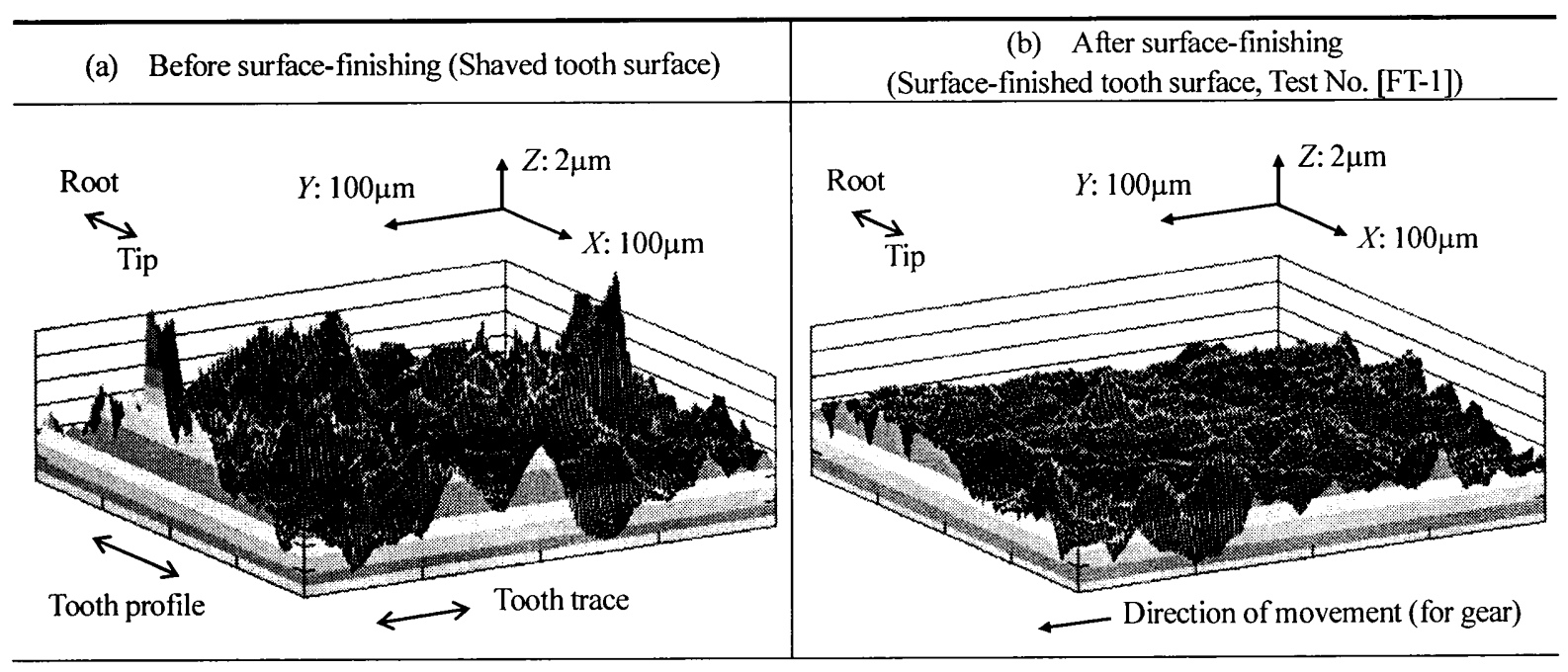

Fig. 3 Bird' eye views (X scan map) of tooth surface before and after finishing (near the pitch line, square region of $400 \mu \mathrm{m}$ ) 
して, それぞれ歯形方向 $400 \mu \mathrm{m}$ と歯すじ方向 $400 \mu \mathrm{m}$ の正方形領域のシェービング浸炭㹸入れ歯面並びに仕上 げ歯面の代表例である.なお，図 4 において，等高線閒隔は $0.7 \mu \mathrm{m}$ とし，図中の配色数が少ないほど, 表面の山 と谷の高低差が少ないことを表している.

次に, 図 5 に，三次元形状パラメータの最大高さ $S R \max$ と十点平均粗さ $S R z$ を示す。ここで，図 5 において， 最大高さ $S R \max$ と十点平均粗さ $S R z$ は, 二次元にお打る表面粗さの)定義 ${ }^{(9)}{ }^{(10)}$ を参考に, 断面曲面の平均面に平 行な二つの平面で断面曲面を挟んだ時の間隔と平均面に対し高い方から 5 番目までの山頂の平均高さと深い方か ら 5 番目までの谷底の平均深さの間隔で, 一つの測定歯面についてビッチ線付近の歯形方向 $400 \mu \mathrm{m}$ と歯すじ方 向 $400 \mu \mathrm{m}$ の正方形領域を 9 か所測定し，それぞれの最低值・平均值・最高值で表示している.

図3〜図 5 などから, 本実験条件において, シェービング浸炭焼入れ歯面では, 歯面に著しい突起部が存在す るとともに不規則な凸部が多数確認されること，次に，MVA150，MVB250，MVC590の流動性火山灰を用いた

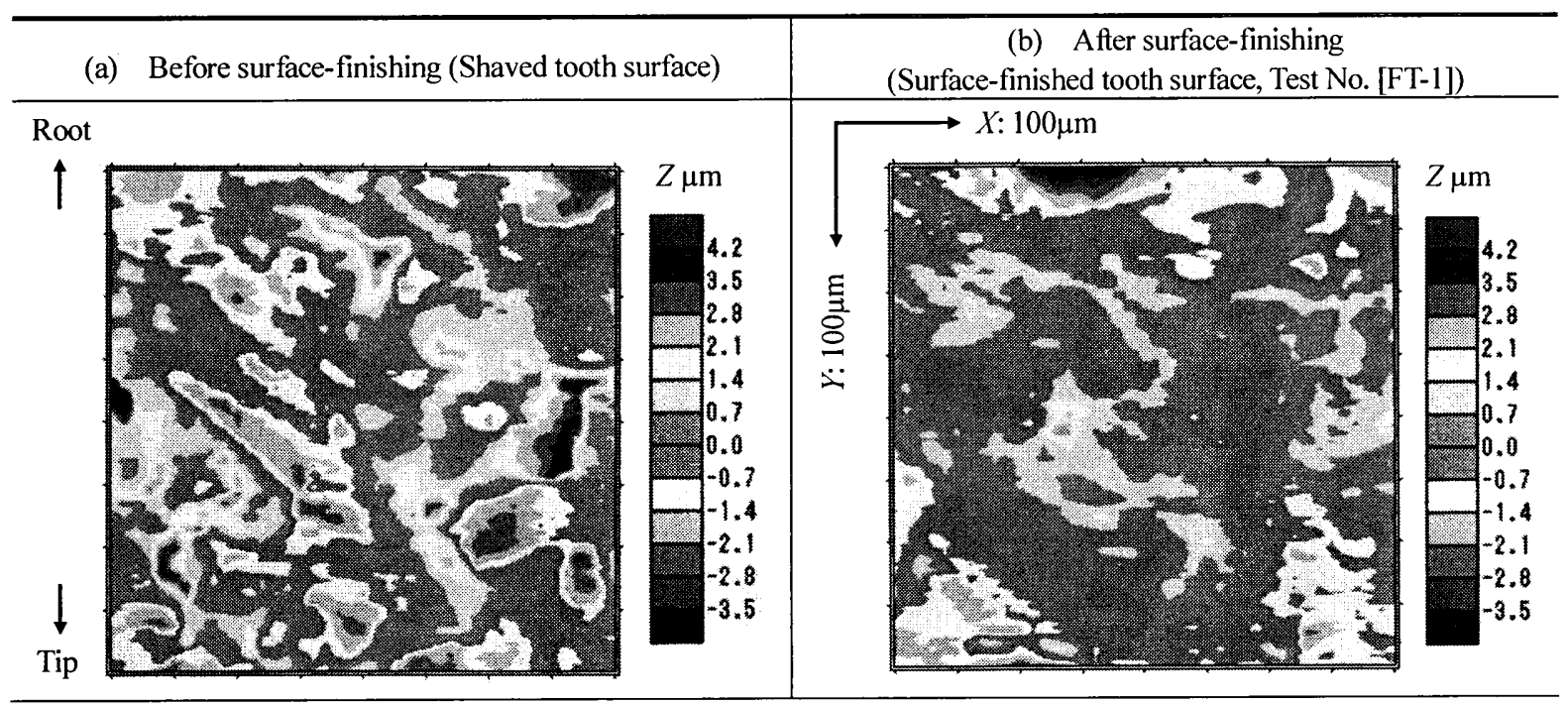

Fig. 4 Flat map (direct contour map) of tooth surface before and after finishing (near the pitch line, square region of $400 \mu \mathrm{m}$ )
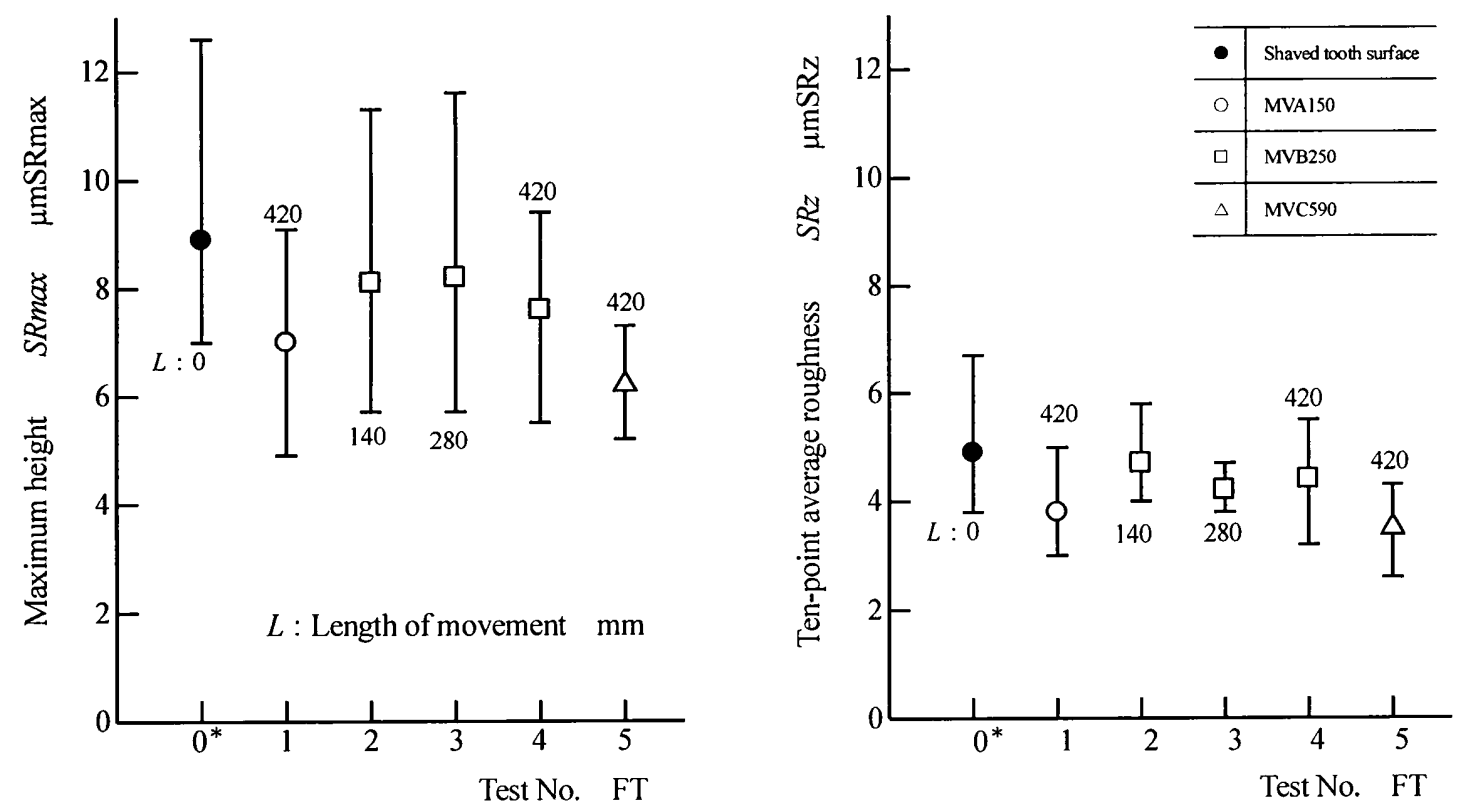

Fig. 5 Three dimensional roughness parameters of shaved tooth surface and surface-finished tooth surface (near the pitch line, square region of $400 \mu \mathrm{m}$ ), * : Shaved tooth surface 
仕上げ歯面では，いずれも，凸部が滑らかになっているがわかった．

\section{$4 \cdot 3$ 表面状況に及ほす仕上げ距離の影留}

図 5 などに抽て，流動性火山灰を一定（MVB250）として，シェービング浸炭焼入れ歯面（実験番号[FT-0*]） と仕上げ歯面の表面状況（実験番号[FT-2] MVB250・[FT-3] MVB250・[FT-4]MVB250）を比較すると，仕上げ歯 面の最大高さ $S R \max$ と十点平均粗さ $S R z$ は, いずれもシェービング浸炭焼入れ歯面に比べ平均值で約 $10 \%$ 程度 減少し, それぞれの值は仕上げ距離の增加で減少する傾向がわかった.

\section{$4 \cdot 4$ 表面状況に及ほすす火山灰の粒徍の影址}

図 5 などにおいて, 仕上げ距離を一定 $(L=420 \mathrm{~mm})$ として, シェービング浸炭焼入れ歯面（実験番号[FT-0*]） と仕上げ歯面の表面状況（実験番号[FT-1] MVB150・[FT-4] MVB250・[FT-5]MVB590）を比較すると，仕上げ歯 面の最大高さ $S R \max$ と卜点平均粗さ $S R z$ の值は，いずれもシェービング浸炭焼入れ歯面に比べ平均值で約 $10 \sim$ $30 \%$ 程度減少し, 可塑性材料に含まれる火山灰の粒径が大きいほど減少する傾向がわかった。

\section{5. 結語}

浸炭焼入れ菌車の歯面強さ向上と加工における環境保全の促進のために, 天然資源の火山灰と白色ワセリンを 混合した可塑性材料を用いた歯面仕上げ法を適用し，歯面性状に及ぼす加工条件の影響を考察・検討した．その 結果, 提案した歯面仕上げ法の適用で, 現在までのところ,

(1) シェービング浸炭焼入れ歯面の熱処理後の不規則な表面あれは，ほとんど消失すること，

(2) シェービング浸炭焼入れ歯面の凸部は, 滑らかになること,

(3) 仕上げ歯面の三次元粗さパラメータの值 $(S R \max \cdot S R z)$ は, シェービング浸炭焼入れ歯面に比べ, 仕上げ距 離の増加と可塑性材料に含まれる火山灰の粒径の増加で減少する傾向にあること, がわかった.

なお，今後の課題として，火山灰を用いた歯面仕上げ法における適用範囲と加工条件の最適化，並びに，実用 化を図る必要がある.

終わりに, 九州武蔵精密株式会社と清新産業株式会社, 並びに, 宮崎大学産学連携センター・ものづくり教育 実践センター・工学部機械システム工学科の各位のご援助・ご協力に対し感謝の意を表する.

\section{文献}

(1)たとえば，東川隆英，“最近の歯車加工機と加工技術”，(日本機械学会）P-SCD359歯車の高機能化と加工技術に関 する調查分科会研究成果報告書, (2010-3), pp.35-40, 日本機械学会.

(2)たとえば, T. Nakanishi, Y. Ariura , "Effect of Surface-Finishing on Surface Durability of Surface-Hardened Gears", Proceedings of the International Conference on Motion and Power Transmissions, Hiroshima, JAPAN, (1991), pp.828 833.

(3)たとえば, 井上克己・前原利之・山中 将・加藤正名, “浸炭歯車の曲げ強度に対するショットピーニングの効果”, 日本機械学会論文集 C 編，Vol.54，No.502 (1988)，pp.1331-1337.

(4)たとえば, 鈴木義友, “トランスミッションと歯車技術動向”, 日本機械学会講演論文集 (機素潤滑設計部門 MPT2004 シンポジウム＜伝動装置＞講演論文集)，No. 04-17 (2004-11), 基調講演 pp.1-4.

(5)中西 勉, 西牟田昌吾, 山本㙇也, 鄧 鋼, “自動車用駆動系歯車の加工と性能に関寸る基礎研究 (火山灰混入の可 塑性材料を用いた歯面仕上げ法)”, 日本機械学会講演論文集 (2010 年度年次大会講演論文集 Vol.4), No.10-1 (2010-9), pp. 91-92.

(6)日本工業規格，“試験用ふるい-第 1 部：金属製網ふるい”, JIS Z8801-1-2006（2006-11）, pp.1-10， 日本規格協会.

(7)日本機械学会編, “生産加工の原理”, (1998), pp.157-167, 日刊工業新聞社.

(8)日本薬局方, 第十四改正日本薬局方 (平成 13 年 3 月 30 日厚生労働省告示第 111 号), “白色ワセリン”, pp.1006-1007, 厚生労働省.

(9)日本工業規格, “表面粗さの定義と表示”，JIS B0601-1982（1982-8）pp.1-20，日本規格協会.

(10)日本工業規格, “製品の幾何特性仕様（GPS） - 表面性状 : 輪郭曲線方式 - 用語, 定義及び表面性状パラメータ”, JIS B0601-2001（2001-1），pp.1-22，日本規格協会. 